\title{
PENGARUH KOMPETENSI PEDAGOGIK DAN SOSIAL GURU PAI TERHADAP KEMAMPUAN BERPIKIR KREATIF SISWA SMK AL-KAHFI SUMBAWA TAHUN PELAJARAN 2018/2019
}

\author{
Muammar Khadafie ${ }^{1}$, Akhairuddin 2 \\ 1,2Program Ilmu Komunikasi, Universitas Teknologi Sumbawa, Indonesia \\ muammar.khadafie.togo@gmail.com ${ }^{1}$, herugagah11@gmail.com ${ }^{2}$
}

\section{INFO ARTIKEL}

\section{Riwayat Artikel:}

Diterima: 15-08-2019

Disetujui: 30-10-2019

\section{Kata Kunci: \\ Kompetensi Pedagogik; Kompetensi Sosial; Kemampuan Berpikir kreatif Siswa.}

\section{Keywords:}

Pedagogic competence; Social competence; Student creative thinking skills.

\section{A. LATAR BELAKANG}

Kompetensi pedagogik merupakan salah satu kompetensi mutlak perlu dikuasai oleh guru karena kompetensi pedagogik adalah kemampuan guru mengelola pembelajaran peserta didik yang meliputi pemahaman terhadap peserta didik. Perencanaan dan pelaksanaan pembelajaran, evaluasi hasil belajar, dan pengembangan peserta didik untuk bisa menguaktualisasikan berbagai

\section{ABSTRAK}

Abstrak: Penelitian ini bertujuan untuk Untuk: Membuktikan ada atau tidak adanya pengaruh kompetensi Pedagogik dan sosial guru PAI terhadap kemampuan berpikir kreatif siswa SMK Al-Kahfi Sumbawa Tahun pelajarn 2018/2019. Penelitian ini menggunakan pendekatan kuantitatif deskriptif dan komparatif dengan tekhnik pengumpulan data menggunakan koesioner/angket, dokumentasi dan observasi. Tekhnik analisi data menggunakan analisis regresi linier sederhana dan regresi linier berganda kemudian di hitung dengan menggunakan aplikasi SPSS 16,0. Hasil perhitungan dengan menggunakan regresi linier sederhana yaitu: 1) Terdapat pengaruh kompetensi pedagogik guru PAI terhadap kemampuan berpikir kreatif siswa, diperoleh nilai signifikansi sebesar $0,000<0,05$ dan nilai $t_{\text {hitung }}$ sebesar $14,566>t_{\text {tabel }} 2,000$. 2) Terdapat pengaruh kompetensi sosial guru PAI terhadap kemampuan berpikir kreatif siswa, diperoleh nilai signifikansi sebesar 0,002 $<0,05$ dan nilai $t_{\text {hitung }}$ sebesar 10,680 $>t_{\text {tabel }} 2,000$. 3) Hasil perhitungan dengan menggunakan regresi liner berganda yaitu Terdapat pengaruh kompetensi pedagogik dan sosial guru PAI terhadap kemampuan berpikir kreatif siswa, nilai signifikansi untuk pengaruh $\mathrm{X}_{1}$ dan $\mathrm{X}_{2}$ secara simultan terhadap $\mathrm{Y}$ adalah sebesar $0,000<0,05$ dan nila $\mathrm{F}$ hitung $11.079>3,11$. pengaruh $\mathrm{X}_{1}$ dan $\mathrm{X}_{2}$ secara simultan terhadap $\mathrm{Y}$.

\begin{abstract}
This research aims to prove the presence of the pedagogic influence and social competence of Islamic education teacher in the creative thinking skills of Vocational High School's student of Alkahfi in academic year 2018/2019. This research uses Quantitative approaches with data collection techniques using questionnaires, documentation, and observations. The data analysistechnique uses simple linier regression analysis and multiple liniear regression then calculated by using the SPSS 16.0 aplication.The calculations with simple liniear regression result are: 1) A pedagogic competence influence Islamic Education teachers to the creative thinking skills of students, acquired significance value of $0.000<0,05$ and the calculated T value of $14.566>$ T Table 2.000. 2) A social competence influence Islamic Education teachers to the creative thinking skills of students, acquired significance value of $0.002<0.05$ and the calculated $T$ value of $10.680>T$ table 2.000. 3) calculation result by using linier regression $A$ double is the influence of the pedagogic and social competence of PAI teacher toward the student's creative thinking, the significance value for the simultaneous influence of XI and X2 against $Y$ is $0.000<0.05$ and the $F$ count $11.079>$ 3.11. Effec of $X 1$ and $X 2$ simultaneously against $Y$.
\end{abstract}

potensi yang dimilikinya. Pencapaian tujuan belajar dalam proses belajar-mengajar hasilnya diukur atau ditentukan dengan suatu hasil belajar. Berhasil tidaknya seorang siswa dalam kegiatan pembelajaran dapat dilihat dari hasil belajar,

Jika guru mengaplikasikan kompetensi pedagogik kepada siswa maka segala informasiinformasi ilmu yang disampaikan kepada siswa seyogyanya dapat diterima dan dilaksanakan dengan baik pula oleh siswa, hal ini sesuai dengan 
kompetensi sosial yang harus dimiliki oleh guru. kompetensi sosial adalah kemampuan guru sebagai suatu bagian dari masyarakat untuk berkomunikasi dan bergaul secara efektif dengan peserta didik, sesama pendidik, tenaga kependidikan, orang tua/wali peserta didik, dan masyarakat di sekitar. Kemampuan ini adalah suatu kemampuan yang harus dimiliki oleh seorang guru untuk menyesuaikan diri terhadap tuntutan pekerjaan dan lingkungan.

Kemampuan berpikir kreatif siswa merupakan kebutuhan yang harus dimiliki individu di era globalisasi. Hal ini didukung oleh pernyataan Munandar bahwa kemajuan teknologi menuntut individu untuk beradaptasi secara kreatif. Kondisi tersebut menuntut siswa untuk menjadi individu yang kreatif, terutama di SMK Al-Kahfi Sumbawa. Individu yang kreatif mampu memberikan kontribusi untuk mengembangkan ilmu pengetahuan dan teknologi. Hal ini dikarenakan individu yang kreatif pasti memiliki kepercayan diri, mandiri, tanggung jawab dan mampu komitmen kepada tugas, tidak kehabisan akal dalam memecahkan sebuah masalah, kaya inisiatif, dan lebih berorientasi kepada masa kini dan masa depan dari pada berorientasi pada masa lalu.

Berdasarkan hasil wawancara di SMK AlKahfi Sumbawa, pada proses pembelajaran PAI siswa sangat antusias mengikuti proses belajar, ketika siswa kurang mengerti penjelasan guru maka siswa langsung bertanya kemudian guru melempar pertanyaan tersebut kepada siswa yang lainnya dan langsung dijawab oleh siswa. Dalam kegiatan proses belajar mengajar rata-rata siswa aktif, pada saat melakukan diskusi kelompok siswa mampu merespon pendapat temannya, dan mendapatkan nilai tugas di atas rata-rata. pak Abdulrohim selaku guru PAI mengatakan bahwa pada dasarnya hal itu juga bergantung pada bagaimana kreativitas guru dalam menerapkan pembelajaran di kelas dan tantangan tersendiri bagi guru dalam menumbuhkan kemampuan berpikir kreatif mereka, agar siswa mampu mengikuti arus perkembangan zaman di abad 21 ini. Hal itu sesuai dengan observasi yang dilakukan oleh peneliti. Peneliti melihat bahwa pada proses pembelajaran guru terlebih dahulu menyiapkan rancangan pembelajaran, menyiapkan buku paket untuk siswa, guru mampu memahami karakteristik siswa dengan memberikan pertanyaan tidak hanya menunjuk satu siswa untuk menjawab tetapi secara menyeluruh, sebelum berakhirnya jam pelajaran guru selalu memberikan tugas rumah, dan melakukan evaluasi tiap bab materi pembelajaran.

Guru PAI di SMK Al-Kahfi Sumbawa dalam mengajar selalu adil, menjadi guru favorit karena sikap Guru PAI yang disiplin rendah hati, tegas, dan menarik sehingga membuat siswa senang mengikuti mata pelajaran PAI. guru PAI di SMK AlKahfi Sumbawa sudah menunjukkan kompetensi sosial dengan baik, seperti guru PAI ramah terhadap siswa, guru berkomunikasi yang baik dengan siswa, menghargai pendapat siswa, tidak egois terhadap siswa, mengarahkan siswa menjawab pertanyaan dengan kasih sayang agar siswa tidak minder dalam proses belajar mengajar, menegur siswa ketika makan dan minum sambil jalan, menegur siswa membuang sampah sembarangan. Hubungan sosial dengan sesama guru seperti guru PAI berkomunikasi dengan sesama guru sangat baik, menghargai pendapat guru lain, membantu sesama guru ketika mendapatkan kesusahan.

Kompetensi pedagogik yang dimiliki oleh guru PAI dapat mengasah kemampuan kognitifnya dan mendapatkan pengalaman belajar langsung bagi siswa. Selain guru PAI mengaktifkan siswa dalam proses pembelajaran, guru PAI juga menciptakan suasana belajar yang menarik bagi siswa yaitu berkominasi yang baik, membina hubungan yang harmonis, menasehati siswa dengan penuh kasih saying, menggunakan kalimat yang lemah lembut.

Ketika kompetensi pedagogik dan kompetensi sosial sudah dimiliki oleh guru siswa dapat mengasah kemampuan kognitifnya, dan juga mendapat pembelajaran langsung sehingga pembelajaran lebih bermakna bagi siswa.

Berdasarkan pemaparan tersebut, maka peneliti tertarik melakukan penelitian dengan tema sebagai berikut pengaruh kompetensi pedagogik dan sosial guru PAI terhadap kemampuan berpikir kreatif siswa SMK Al-Kahfi Sumbawa Tahun Pelajaran 2018/2019.

\section{B. METODE PENELITIAN}

Desain penelitian yang peneliti gunakan dalam melakukan penelitian ini adalah pendekatan kuantitatif deskriptif dan komparatif, "penelitian kuantitatif bertujuan untuk membuktikan teori, menunjukkan pengaruh antar variabel dan membuat prediksi". Peneliti menggunakan rumus regresi linier berganda karena sesuai dengan masalah yang akan diteliti dan data yang akan dikumpulkan merupakan data yang berupa angka, selanjutnya ditabulasi dalam bentuk tabel yang disediakan. Adapun teknik pengumpulan data yaitu, koesioner/angket, dokumentasi dan observasi, wawncara. 


\section{HASIL DAN PEMBAHASAN}

\section{Pengaruh kompetensi pedagogik terhadap kemampuan berpikir kreatif siswa SMK Al- Kahfi Sumbawa Tahun pelajaran 2018/2019.}

Pedagogik mempunyai arti ilmu mendidik. Kompetensi pedagogik merupakan suatu performansi (kemampuan) seseorang dalam bidang ilmu pendidikan untuk menjadi guru yang professional harus memiliki kompetensi Pedagogik. Seorang guru harus memiliki pengetahuan dan pemahaman serta memiliki kemampuan dan keterampilan pada bidang profesi kependidikan.

Kompetensi pedagogik meliputi, kemapuan guru dalam menjelaskan materi, melaksanakan metode pembelajaran, memberikan pertanyaan, menjawab pertanyaan, mengelola kelas, dan melakukan evaluasi, (M. Saekhan Muchith) Menurut Jamil Suprihatiningrum, bahwa : "kompetensi pedagogik merupakan kemampuan yang berkaitan dengan pemahaman siswa dan mengelola pembelajaran yang mendidik dan dialogis. Menurut pendapat Ramayulis, bahwa yang dimaksud dengan kompetensi pedagogik yakni antara lain kemampuan pemahaman tentang peserta didik secara mendalam dan penyelenggaraan pembelajaran yang mendidik. Kompetensi pedagogik guru ditandai dengan kemampuannya menyelenggarakan proses pembelajaran yang bermutu, serta sikap dan tindakan yang dapat dijadikan teladan.

Dari penjelasan di atas, maka dapat dipahami bahwa yang dimaksud dengan kompetensi pedagogik, adalah pemahaman guru mengenai peserta didik serta pengelolaan atau pemanajemenan pembelajaran, yang berguna untuk mengetahui karakteristik peserta didik sehingga bisa mengetahui apa yang dibutuhkan dan diperlukan oleh peserta didik

Dengan demikian kemampuan pedagodik bagi guru bukanlah hal sederhana karena kualitas seorang guru haruslah di atas rata-rata. Kualitas ini dapat diliahat dari aspek intelektual meliputi: Pertama, logika sebagai pengembangan kognitif mencakup kemampuan intelektual mengenai lingkungan terdiri atas empat macam yang disusun secara hierarkis darai yang sederhana sampai kepada yang kompleks, yaitu: pengetahuan, pemahaman, penerapan, dan analisis. Kedua, kemampuan afektif mencakup kemampuan emosional disusun secara hierarkis, antara lain: kesadaran, partisipasi, pengahayatan nilai, pengorganisasian nilai, dan karakteristik diri. Ketiga, estetika sebagai pengembangan psikomotorik, yaitu kemampuan motorik mengingatkan dan mengkoordinasikan gerakan, yaitu terdiri dari: gerakan reflek, gerakan dasar, kemampuan perseptual, kemampuan jasmani, gerakan terlatih, dan komunikasi non-diskursif.

Guru dituntut untuk meningkatkan kualitas belajar para peserta didik dalam kegiatan belajar, sehingga dapat mengasilkan pribadi yang mandiri pelajar yang efektif dan bekerja yang produktif. Dalam hubungan ini, guru memegang peranan penting dalam menciptakan suasana belajar dan mengajar yang sebaik-baiknya, tugas guru dalam mengajar, tidak hanya sebagai pengajar dalam arti hanya penyampai pengetahuan, tetapi lebih meningkat sebagai perancang pengajaran, manager pengajar, pengevaluasi hasil belajar dan sebagai direktur belajar. Dengan muatan tanggungjawab guru terkait dengan kompetensi pedagogik akan mengantarkan siswa dapat memahami dam berpikir kreatif terhadap menyelesaikan berbagai masalah.

Hasil penelitian para riset yang menemukan bahwa siswa yang merasa punya guru yang suportif dan perhatian akan lebih termotivasi untuk belajar daripada siswa yang merasa punya guru yang tidak suportif dan perhatian (McCombs, 2001; mewman, 2002; Ryan \& Deci, 2000, dalam santroc, 2010). Starategi dan pendekatan belajar (memiliki kemampuan untuk membedakan kurikulim siswa berbakat, menggunakan strategi yang mampu mendorong level berpikir yang lebih tinggi, memberikan pembelajaran student-centred, berperan sebagai fasilitator, membentuk lingkungan belajar yang tidak mengancam, terorganisir), dan karakteristik intelektual (mempunyai pemahaman yang mendalam mengenai bahan ajar, memiliki ketertarika yang luas dalam literatur maupun cultural, pembelajar yang berkelanjutan, memiliki intelegensi di atas rata-rata, berpikir kreatif, memiliki kemampuan komunikasi yang hebat).

Adanya keeratan hubungan antara kompetensi pedagogik dengan kemampuan berpikir kreatif siswa SMK Al-Kahfi Sumbawa tahun Pelajaran 2018/2019 dilihat pada correlation dengan hasil signifikansi sebesar 0,000 dan koefisien korelasi sebesar 0,395 yang artinya, telah terjadi korelasi antara kompetensi pedagogik terhadap kemampuan berpikir kreatif siswa.

Berdasarkan hasil pengolahan data menerangkan bahwa terdapat pengaruh kompetensi pedagogik guru PAI terhadap kemampuan berpikir kretaif siswa di SMK Al-Kahfi Sumbawa, yang dibuktikan dengan adanya hubungan yang linier antara variabel kompetensi pedagogik dan kemampuan berpikir kreatif siswa 
di lihat dari nilai nilai $\mathrm{F}_{\text {hitung }}=14,566>2,000$. Ada hubungan yang signifikan antara variabel kompetensi pedagogik dan kemampuan berpikir kreatif dengan tingkat signifiknsi sebesar 0,000< 0,05 .

Kostanta (a) sebesar 24,057, mengandung arti bahwa nilai konsisten variabel kemampuan berpikir kreatif adalah positif yaitu sebesar 24,057, koefisien regresi variabel kompetensi pedagogik $\mathrm{X}_{1}$ sebesar 0,495 menyatakan bahwa setiap penambahan 1 nilai kompetensi pedagogik, maka nilai kemampuan berpikir kreatif bertambah sebesar 0,495. Koefisien tersebut bernilai positif. Sehingga dapat dikatakan bahwa arah pengaruh variabel $\mathrm{X}_{1}$ terhadap $\mathrm{Y}$ adalah positif yang artinya perolehan koefisien sebesar 0,495 tersebut memberikan interpretasi bahwa responden yang memiliki kompetensi pedagogik akan berbanding lurus dengan kemampuan berpikir kreatif siswa. Dalam artian, peningkatan kompetensi pedagogik guru PAI dapat meningkatkan kemampuan berpikir kreatif siswa. Kemudian koefisisen determinasi (R Square) sebesar 0,156, yang mengandung pengertian bahwa pengeruh variabel bebas (kompetensi pedagogik) terhadap variabel terikat (kemampuan berpikir kreatif) adalah sebesar $15,6 \%$. 84,4\% dipengaruhi oleh variabel lainnya.

Berdasarkan hasil penelitian pembagian koesioner/angket tentang pengaruh kompetensi pedagogik terhadap kemampuan berpikir kreatif siswsa SMK Al-Kahfi Sumbawa Tahun pelajaran 2018/2019 terdapat hubungan yang linier, signifikan dan koefisien bernilai positif yang artinya hipotesis dugaan sementara diterima. Jadi kompetensi pedagogik berpengaruh terhadap kemampuan berpikir kreatif siswa SMK Al-Kahfi Sumbawa Tahun pelajaran 2018/2019.

\section{Pengaruh kompetensi sosial Guru PAI terhadap berpikir kreatif siswa SMK Al-Kahfi Sumbawa Tahun Pelajaran 2018/2019.}

Subagyo mengemukakan bahwa kompetensi sosial adalah kemampuan untuk berkomunikasi dan berinteraksi secara efektif dan efisien, baik dengan peserta didik, guru ,orang tua/wali, dan masyarakat sekitar, sehingga seorang yang memiliki kompetensi sosial akan nampak menarik, empati, kolaboratif, suka menolong, menjadi panutan, komunikatif, dan kooperatif. Kompetensi sosial adalah kemampuan guru sebagai bagian dari masyarakat untuk berkomunikasi dan berinteraksi secara efektif dengan peserta didik, sesama pendidik, tenaga kependidikan, orang tua/wali peserta didik, dan masyarakat sekitar.

Dapat disimpulkan bahwa kompetensi sosial guru adalah kemampuan dan kecakapan seorang guru dalam berkomunikasi dan berinteraksi secara efektif pada pelaksanaan proses pembelajaran serta masyarakat sekitar.

Guru adalah makhluk sosial, dalam kehidupannya tidak akan bisa terlepas dari kehidupan sosial masyarakat dan lingkungan sekitar, oleh karena itu guru di tuntut untuk memiliki kompetensi sosial yang memadai, terutama kaitannya dengan pendidikan, yang tidak terbatas pada pembelajaran yang ada di sekolah tetapi juga pada pendidikan yang terjadi dan berlangsung di lingkungan masyarakat.

Inti dari kompetensi sosial terketak pada komunikasi, tetapi komunikasi yang dimaksud adalah komunikasi yang efektif. Komunikasi dapat diartikan sebagai suatu proses saling mempengaruhi antar manusia. Komunikasi juga merupakan keseluruhan dari pada perasaan, sikap dan harapan-harapan yang disampaikan, baik secara langsung atau tidak langsung, baik yang dilakukan secara sadar atau secara tidak sadar karena komunikasi merupakan bagian integral dari proses perubahan.

Pengujian Literatur yang dilakukan oleh (Vialle \& Quigley, 2002, dalam Tiscler \& Vialle, 2009) menunjukkan kunci dan karakteristik guru dari siswa berbakat terbagi menjadi tiga area, yakni karakteristik personal-sosial (memiliki insting mengenai kebutuhan kognitif, sosial, dan emosional siswa, memiliki selera humor, menerima kesalahan, antusias, dan responsive secara cultural). Menurut Wentzel \& Wigfield, guru yang efektif dideskripsikan secara tipikal menjadi guru yang mampu mengembangkan hubungan emosional secara dengan siswa, siswa merasa aman, dapat dipercaya oleh siswa, yang memberikan akses untuk batuan instrumental, membantu perkembangan etos dari komunitas, dan menyediakan kelas yang saling peduli. Kenyamanan bekerja memdukung kemampuan berpikir kreatif siswa.

Berdasarkan hasil pengolahan data menerangkan bahwa terdapat pengaruh pengaruh kompetensi sosial guru PAI terhadap kemampuan berpikir kretaif siswa di SMK Al-Kahfi Sumbawa, yang dibuktikan dengan perolehan koefisien sebesar 0,430. Angka kaoefisien regresi tersebut memberikan interpretasi bahwa responden yang memiliki kompetensi sosial akan berbanding lurus dengan kemampuan berpikir kreatif siswa. Dalam artian, peningkatan kompetensi sosial guru PAI dapat meningkatkan kemampuan berpikir kreatif siswa.

Adanya keeratan hubungan antara kompetensi sosial dengan kemampuan berpikir kreatif siswa SMK Al-Kahfi Sumbawa tahun 
Pelajaran 2018/2019 dilihat pada correlation dengan hasil signifikansi sebesar 0,002 dan koefisien korelasi sebesar 0,345 yang artinya, telah terjadi korelasi antara kompetensi sosial terhadap kemampuan berpikir kreatif siswa.

Berdasarkan hasil pengolahan data menerangkan bahwa terdapat pengaruh kompetensi sosial guru PAI terhadap kemampuan berpikir kretaif siswa di SMK Al-Kahfi Sumbawa, yang dibuktikan dengan adanya hubungan yang linier antara variabel kompetensi sosial dan kemampuan berpikir kreatif siswa di lihat dari nilai nilai $F_{\text {hitung }}=10,680>2,000$. Ada hubungan yang signifikan antara variabel kompetensi sosial dan kemampuan berpikir kreatif dengan tingkat signifiknsi sebesar 0,002 $<0,05$.

Kostanta (a) sebesar 26,530 mengandung arti bahwa nilai konsisten variabel kemampuan berpikir kreatif adalah positif yaitu sebesar 26,530 , Koefisien regresi variabel kompetensi sosial $\mathrm{X}_{2}$ sebesar 0,430 menyatakan bahwa setiap penambahan 1 nilai kompetensi sosial, maka nilai kemampuan berpikir kreatif bertambah sebesar 0,430 . Koefisien tersebut bernilai positif. Sehingga dapat dikatakan bahwa arah pengaruh variabel $\mathrm{X}_{2}$ terhadap Y adalah positif yang artinya perolehan koefisien sebesar 0,430 tersebut memberikan interpretasi bahwa responden yang memiliki kompetensi sosial akan berbanding lurus dengan kemampuan berpikir kreatif siswa. Dalam artian , peningkatan kompetensi sosial guru PAI dapat meningkatkan kemampuan berpikir kreatif siswa. Kemudian koefisisen determinasi ( $\mathrm{R}$ Square) sebesar 0,119, yang mengandung pengertian bahwa pengeruh variabel bebas (kompetensi sosial) terhadap variabel terikat (kemampuan Berpikir Kreatif) adalah sebesar 11,9\% .

Berdasarkan hasil penelitian pembagian koesioner/angket tentang pengaruh kompetensi sosial terhadap kemampuan berpikir kreatif siswa SMK Al-Kahfi Sumbawa Tahun pelajaran 2018/2019 terdapat hubungan yang linier, signifikan dan koefisien bernilai positif yang artinya hipotesis dugaan sementara diterima. Jadi kompetensi sosial berpengaruh terhadap kemampuan berpikir kreatif siswa SMK Al-Kahfi Sumbawa Tahun pelajaran 2018/2019.

\section{pengaruh kompetensi pedagogik dan kompetensi sosial guru PAI Terhadap Berpikir Kreatif Siswa SMK Al-Kahfi Sumbawa Tahun Pelajarn 2018/2019}

Dalam rangka peningkatan mutu pendidikan seorang guru mempunyai peranan yang penting dalam merealisasikan tujuan pendidikan nasional.
Guru sebagai ujung tombak dalam kegiatan belajar mengajar di sekolah yang langsung berhadapan dengan siswa. Tanpa adanya peranan guru, maka kegiatan proses belajar mengajar tidak akan berjalan dengan semestinya.

Kompetensi guru dapat dimaknai sebagai kebulatan pengetahuan keterampilan dan sikap yang berwujud tindakan cerdas dalam melaksanakan tugas guru sebagai agen pembelajaran'. Kompetensi guru merupakan kemampuan dasar yang harus dimiliki oleh guru yang pengaruhnya sangat besar sekali terhadap berpikir kreatif siswa.

Kompetensi pedagogik dan kompetensi sosial guru mempengaruhi peningkatan berpikir kreatif siswa. Guru yang dapat mengelola pembelajaran dan berjiwa sosial akan lebih mudah menciptakan lingkungan belajar yang efektif, menyenangkan dan akan mampu mengelola kelasnya, sehingga proses belajar mengajar para siswa akan berada pada tingkat optimal. Kompetensi Pedagogik guru sangat mempengaruhi perannya sebagai pendidik dan pembimbing, pemahaman terhadap peserta didik , perencanaan dan pelaksanaan, evaluasi hasil belajar dan pengembangan peserta didik dapat mengaktualisasikan berbagai potensi yang dimilikinya. Guru juga diharapkan membina hubungan baik dengan siswa, dengan sesama guru di lingkungan sekolah, orang tua siswa, dan berhubungan baik dengan masyarakat sekitar sekolah atau masyarakat yang lebih luas untuk kepentingan pendidikan. Oleh sebab itu kompetensi pedagogik dan kompetensi sosial menjadi syarat penting seorang guru agar semakin berpengaruh positif terhadap kemampuan berpikir kreatif siswa. Untuk membuat siswa mampu berpikir kreatif tidaklah mudah perlu adanya upaya dan kerja keras yang serius dari para guru, kemampuan berpikir kreatif sangat perlu dilatih sejak dini melalui pembiasaan secara konsisten. Hal ini ditegaskan oleh Russeffendi mengatakan bahwa manusia yang kreatif itu tidak hanya baik bagi dirinya tetapi juga berfaedah bagi orang lain.

Menurut Yusuf berpikir kreatif (Creative thinking), yaitu kemampuan berpikir dengan caracara baru dan menemukan pemecahan masalah secara unik. Kemampuan berpikir bukan berpikir konvergen (yang menghasilkan satu jawaban benar), tetapi berpikir divergen (yang menghasilkan bnyak jawaban untuk petanyaan yang sama). Sedangkan menurut munandar mengatakan berpikir kreatif merupakan kemampuan untuk memberikan gagasan-gagasan yang baru dapat diterapkan dalam pemecahan masalah. Siswa yang kreatif selalu mempunyai rasa 
ingin tahu ingin mencoba-coba, berpetualang, memiliki bnyak ide dan mampu mngelaborasi bnyak pendapat. Dengan demikian dapat disimpulkan bahwa berpikir kreatif adalah kemampuan yang dimiliki individu untuk memberikan gagasan-gagasan yang baru dalam memecahkan masalah.

Kemampuan berpikir kreatif merupakan kebutuhan yang harus dimiliki individu di era globalisasi ini. Ini didukung oleh pernyataan Munandar bahwa kemajuan teknologi sangat menuntut individu untuk beradaptasi secara kreatif. Kondisi tersebut menuntut siswa untuk menjadi individu yang kreatif, terutama di SMK Al-Kahfi Sumbawa. Individu yang kreatif yang mampu memberikan kontribusi untuk mengembangkan ilmu pengetahuan dan teknologi. Hal ini dikarenakan individu yang kreatif memiliki kepercayan diri, mandiri, penuh tanggung jawab dan komitmen kepada tugas, tidak kehabisan akal dalam memecahkan suatu masalah, kaya inisiatif, dan lebih berorientasi kepada masa kini dan masa depan dari pada masa lalu.

Ketika kompetensi pedagogik dan kompetensi sosial sudah dimiliki oleh guru siswa dapat mengasah kemampuan kognitifnya, juga mendapat pembelajaran langsung sehingga berpikir kreatif siswa dalam proses pembelajaran menjadi lebih bermakna bagi siswa. Menurut cashdan \& welsh dalam supriadi menemukan bahwa, peserta didik yang tinggi kreativitasnya lebih mandiri, mengusahakan suatu perubahan dalam lingkungannya, dalam relasi interpersonalnya lebih terbuka dan lebih aktif, sebaliknya peserta didik yang rendah kreativitasnya lebih rendah otonominya dan kurang menonjolkan dirinya.

Pieget (dalam Mujis \& Reynolds, 2008) mengatakan bahwa untuk memahami bagaimana anak berpikir harus melihat perkembangan kualitatif dari kemampuan mereka mengatasi masalah. Untuk mengembangankan kemampuan mereka mengatasi masalah. Dari hal itu guru harus mampu mengembangkan kompetensi pedagogik dan sosial nya agar mampu mengasah kemampuan berpikir kreatif siswa.

Berdasarkan hasil pengolahan data menerangkan bahwa terdapat pengaruh pengaruh kompetensi pedagogik dan sosial guru PAI terhadap kemampuan berpikir kretaif siswa di SMK Al-Kahfi Sumbawa, yang dibuktikan dengan perolehan koefisien sebesar 0,413 $\mathrm{X}_{1}$ dan 0,329 $\mathrm{X}_{2}$. Angka kaoefisien regresi tersebut memberikan interpretasi bahwa responden yang memiliki kompetens pdagogik dan sosial akan berbanding lurus dengan kemampuan berpikir kreatif siswa.
Dalam artian, peningkatan kompetensi pedagogik dan sosial guru PAI dapat meningkatkan kemampuan berpikir kreatif siswa.

Adanya keeratan hubungan antara kompetensi pedagogik dan sosial terhadap kemampuan berpikir kreatif siswa SMK Al-Kahfi Sumbawa tahun Pelajaran 2018/2019 dilihat pada correlation dengan hasil signifikansi sebesar 0,027 dan koefisien korelasi sebesar 0,246 yang artinya, telah terjadi korelasi antara kompetensi sosial terhadap kemampuan berpikir kreatif siswa.

Berdasarkan hasil pengolahan data menerangkan bahwa terdapat pengaruh kompetensi pedagogik dan sosial guru PAI terhadap kemampuan berpikir kretaif siswa di SMK Al-Kahfi Sumbawa, yang dibuktikan dengan adanya hubungan yang linier antara variabel kompetensi pedagogik dan sosial terhadap kemampuan berpikir kreatif siswa di lihat dari nilai nilai $\mathrm{F}_{\text {hitung }}=$ $11,079>3,11$. Ada hubungan yang signifikan antara variabel kompetensi pedagogik dan sosial terhadap kemampuan berpikir kreatif dengan tingkat signifiknsi sebesar 0,000 $<0,05$.

Adapun persamaan regresi linier berganda yaitu : Y (kemampuan berpikir kreatif) $=10,831+$ $0,413 X_{1}+0,329 X_{2}$. Kostanta (a) sebesar 10,831 mengandung arti bahwa nilai konsisten nilai koefisien regresi variabel kompetensi pedagogik (b) bernilai positif, yaitu 0,413; ini dapat di artikan bahwa setiap peningkatan kompetensi pedagogik sebesar 1 maka kompetensi pedagogik akan meningkat sebesar 0,413 . Sedangkan pada variabel kompetensi sosial (c) juga bernilai positif, yaitu 0,329, ini dapat diartikan bahwa setiap peningkatan kompetensi sosial sebesar 1, maka kompetensi sosial akan meningkat sebesar 0,329.

Koefisien tersebut bernilai positif. Sehingga dapat dikatan bahwa arah pengaruh variabel $\mathrm{X}_{1}$ dan $\mathrm{X}_{2}$ terhadap $\mathrm{Y}$ adalah positif yang artinya perolehan koefisien sebesar 0,413 dan 0,329 tersebut memberikan interpretasi bahwa responden yang memiliki kompetensi pedagogik dan sosial akan berbanding lurus dengan kemampuan berpikir kreatif siswa. Dalam artian , peningkatan kompetensi pedagogik dan sosial guru PAI dapat meningkatkan kemampuan berpikir kreatif siswa. Kemudian koefisisen determinasi (R Square) sebesar 0,221, yang mengandung pengertian bahwa pengeruh variabel bebas (kompetensi pedagogik dan sosial) terhadap variabel terikat (kemampuan berpikir kreatif) adalah sebesar $22,1 \%$.

Setelah dilakukan beberapa analisis data, penelitian ini dapat diambil kesimpulan bahwa kompetensi pedagogik $\left(\mathrm{X}_{1}\right)$ dan kompetensi sosial $\left(\mathrm{X}_{2}\right)$ secara langsung berpengaruh signifikan secara 
positif terhadap kemampuan berpikir kreatif $(\mathrm{Y})$ masing-masing 0,413, dan 0,329 yang artinya dari kedua variabel tersebut dapat meningkatkan kemampuan berpikir kreatif siswa SMK Al-Kahfi Sumbawa dan mempunyai pengaruh terhadap kemampuan berpikir kreatif SMK Al-Kahfi Sumbawa sebesar 22,1\%.

Berdasarkan hasil penelitian pembagian koesioner/angket tentang pengaruh kompetensi pedagogik dan sosial terhadap kemampuan berpikir kreatif siswa SMK Al-Kahfi Sumbawa Tahun pelajaran 2018/2019 terdapat hubungan yang signifikan positif yang artinya hipotesis dugaan sementara diterima. Jadi kompetensi pedagogik dan sosial berpengaruh terhadap kemampuan berpikir kreatif siswa SMK Al-Kahfi Sumbawa Tahun pelajaran 2018/2019. Oleh karena itu dugaan awal yang mengatakan pengaruh kompetensi pedagogik dan sosial guru PAI terhadap berpikir kreatif siswa SMK Al-Kahfi Sumbawa Tahun pelajaran 2018/2019 benar terbukti.

\section{KESIMPULAN}

Berdasarkan hasil analisis data dan pembahasan pada pengujian hipotesis disimpulkan :

1. Terdapat pengaruh kompetensi pedagogik guru PAI terhadap kemampuan berpikir kreatif siswa SMK Al-Kahfi Sumbawa Tahun Pelajaran 2018/2019, digunakan rumus regresi linier sederhana dengan menggunakan aplikasi SPSS. Kompetensi Pedagogik $\left(\mathrm{X}_{1}\right)$ terhadap kemampuan berpikir kreatif (Y) diperoleh nilai signifikansi sebesar $0,000<$ 0,05 dan nilai $t_{\text {hitung }}$ sebesar $14,566>t_{\text {tabel }} 2,000$, maka kontribusi Ho ditolak dan Ha diterima. Kemudian koefisisen determinasi (R Square) sebesar 0,156 , yang mengandung pengertian bahwa pengeruh variabel bebas (kompetensi pedagogik) terhadap variabel terikat (kemampuan berpikir kreatif) adalah sebesar $15,6 \%$

2. Terdapat pengaruh kompetensi sosial guru PAI terhadap kemampuan berpikir kreatif siswa SMK Al-Kahfi Sumbawa Tahun Pelajaran 2018/2019, digunakan rumus regresi linier sederhana dengan menggunakan aplikasi SPSS. Kompetensi Sosial $\left(\mathrm{X}_{2}\right)$ terhadap kemempuan berpikir Kreatif $(\mathrm{Y})$ diperoleh nilai signifikansi sebesar $0,002<0,05$ dan nilai $t_{\text {hitung }}$ sebesar $10,680>t_{\text {tabel }} 2,000$, sehingga disimpulkan bahwa variabel $\mathrm{X}_{2}$ berpengaruh terhadap Variabel Y. Kemudian koefisisen determinasi (R Square) sebesar 0,119, yang mengandung pengertian bahwa pengeruh variabel bebas (kompetensi sosial) terhadap variabel terikat (kemampuan Berpikir Kreatif) adalah sebesar $11,9 \%$.

3. Terdapat pengaruh kompetensi pedagogik dan sosial guru PAI terhadap kemampuan berpikir kreatif siswa SMK Al-Kahfi Sumbawa Tahun Pelajaran 2018/2019, digunakan rumus regresi ganda dengan menggunakan aplikasi SPSS. Kompetensi Pedagogik $\left(\mathrm{X}_{1}\right)$ dan Sosial $\left(\mathrm{X}_{2}\right)$ terhadap kemampuan berpikir kreatif $(Y)$ nilai signifikansi untuk pengaruh $\mathrm{X}_{1}$ dan $\mathrm{X}_{2}$ secara simultan terhadap Y adalah sebesar $0,000<$ 0,05 dan nila $\mathrm{F}$ hitung $11.079>3,11$, sehingga dapat disimpulkan bahwa H3 diterima yaitu terdapat pengaruh $\mathrm{X}_{1}$ dan $\mathrm{X}_{2}$ secara simultan terhadap $\mathrm{Y}$ dan mempunyai pengaruh terhadap kemampuan berpikir kreatif SMK Al-Kahfi Sumbawa sebesar $22,1 \%$.

\section{DAFTAR RUJUKAN}

Ahmad Mustamil Khoiron \& Eddi Sutadji, "Kontribusi Implementasi Pendidikan Karakter dan Lingkungan Sekolah terhadap Berpikir Kreatif serta Dampaknya pada Kompetensi Kejuruan", Jurnal Pendidikan dan Pembelajaran, Volume 22 Nomor 2, Oktober 2015.

Alfira Mulya Astuti, Statistika Penelitian, Mataran : Insan Madani Publishing Mataram, 2016.

Anasa Sudijono, Statistik Pendidikan, Jakarta: PT Grafindo Persada, 2012.

As'adut Tabi'in, "Kompetensi Guru dalam Meningkatkan Motivasi Belajar pada MTsn Pekana Heran Indragri Hulu", Jurnal ALThariqah 1, no 2 Desember 2016.

Asef Umar Fakhruddin, Menjadi Guru Faforit (Pengenalan, Pemahaman, dan Praktek mewujudkannya), Yogyakarta: Diva Press, 2009.

Chaerul Rohman dan Heri Gunawan, Pengembangan Kompetensi Kepribadian Guru; Menjadi Guru Yang di Cintaidan di Teladani oleh Siswa. Bandung: Nuansa Cendekia, 2012.

Dedeh Tresnawati Choridah, "Peran Pembelajaran Berbasis Masalah untuk Meningkatkan Kemampuan Komunikasi dan berpikir Kreatif Serta Disposisi Matematis Siswa SMA", Jurnal Ilmiah Program Studi Matematika STKIP Siliwangi Bandung . Vol 2, No 2, September 2013. 
E. Mulyasa, Standar Kompetensi dan Sertifikasi Guru, Bandung : PT Remaja Rosdakarya, 2010.

Euis karwati \& Donni Juni Priansa, Manajemen Kelas; Guru Profesional Yang Inspiratif, Kreatif, Menyenangkan, Dan Berprestasi, Bandung: Alfabeta, 2015.

Evis Karwati dan Donni Juni Priansa, Manajemen Kelas Guru Profesional yang Inspiratif, Kreatif, menyenangkan, dan Berprestasi. Bandung: Alfabeta, 2015.

Faisal Subair, "Karakteristik Perusahaan dan Industri Terhadap Pengungkapan dalam Laporan Keuangan pada Perusahaan Manufaktur yang Go Publik", Jurnal Emba Vo. 1 No.3 Juni 2013.

Febri Dwi Cahyani, Fitri Andriani, " Hubungan Antara Presepsi Siswa Terhadap Kompetensi Pedagogik, Kompetensi Kepribadian, dan Kompetensi Sosial Giuru dengan Motivasi Berpretasi siswa Akselerasi di SMA Negeri 1 Gersik", Jurnal Psikologi Pendidikan dan Perkembangan Vol. 3 No. 2, Agustus 2014.

Feralis Novalis, KompetensiGuru dalam Meningkatkan Prestasi Belajar pada SMP Negeri dalam Kota Banda Aceh, Jurnal Administrasi Pendidikan Pascasarjana Universitas Syiah Kuala Volume 3 No. 1, Februari 2015.

Fitriani Nur Sholichan, "Pengaruh EQ (Emotional Quotient) dan SQ (Spiritual Quotient) Terhadap Prestasi Belajar Siswa Pada Mata Pelajaran PAI Di Sekolah Menengah Pertama (SMP) Plus Al-Kautsar Blimbing-Malang", Tesis.

H.A.R Tilaar, Pengembangan Kreativitas dan Entrepreneurship, Jakarta: Kompas Media Nusantara, 2012.

Hendra Surya, Strategi Jitu Mencapai Kesuksesan Belajar. Jakarta: Gramedia, 2011.

Himpunan Peraturan Perundang-Undangan Republik Indonesia, Guru dan Dosen. Bandung : CV. Nuansa Aulia, 2006.

https://www.spssindonesia.com/2014/02/analisi s-regresi-multipes-dengan-spss.html, 18/05/2019, pkl 14.24 wita.

Ismail, "Peningkatan Kompetensi Pedagogik guru PAI dalam Pembelajaran", Jurnal Mudarrisuna, Volume 4 Nomor 2, JuliDesember 2015.

Lalu Mukhtar \& Hully, Profesi Keguruan Tutuntan Bagi Para Pendidikan, Mataram: Alam Tara Institut, 2012.

Mahmud, Psikologi Pendidikan. Bandung: CV Pustaka Setia, 2012.
Maimun, Menjadi guru yang dirindukan, pelita yang menerangi jalan hidup siswa, Yogyakarta: Kurnia Alam Semesta, 2011.

Muh Ilyas Ismail, Kinerja dan kompetensi Guru dalam pembelajaran",Lentera Pendidikan, Vol. 13 No. 1, 1 Juni 2010.

Reni Fahdini dkk, Identifikasi Kompetensi Guru Sebagai Cerminan Profesionalisme Tenaga Pendidikan di Kabupaten Sumedang, Jurnal Mimbar Sekolah Dasar, Volume 1 Nomor 1, April 2014.

Rusdiana, Pengelolaan Pendidikan, Bandung: Pustaka setia, 2015.

Sa'adah, Pengeruh Kompetensi Kepribadian dan Kompetensi Sosial Guru terhadap Motivasi Belajar siswa di Madarasah AliyahMa'arif Bangil, hlm.3 Di akses 18 Desember 2018, homepage:

http://ejournal.iaida.ac.id/index.php/procee ding/article/download/143/137/

Sri Koriaty DKK, "Pengaruh Kompetensi Guru Terhadap Motivasi Belajar Siswa SMK Negeri Jurusan TKJ Sekota Pontianak", Jurnal pendidikan informatika dan sains, Vol 6. No 1. Juni 2017.

Sudarlan dan arifadin, Pengaruh Kompetensi Sosial dan Kompetensi Kepribadian Terhadap Kinerja Dosen di Jurusan Akutansi Politeknik Negeri Samarinda, "Jurnal Eksis Vol. 12, No 1, tahun 2016, $5 . \quad$ http://ejournal.polnes.ac.id/index.php/eksis/article /download/48/27

Sugiono, Statistik Untuk Penelitian. Bandung : Alfabeta, 2015

Sugiyono, Metode Penelitian Kuantitatif Kualitatif dan R\&D. Bandung : Alfabeta, 2013.

Syaiful Sagala, Kemampuan Profesional Guru Dan Tenaga Kependidikan, Bandung: Alfabeta, 2011.

Syofian Siregar, Statistik Parametrik untuk Penelitian Kuantitatif. Jakarta: Bumi Aksara, 2014

Tatang Yuli Eko Siswano, Abdul Haris Rosyidi, Yuliani Puji Astuti, Ika Kurniasari, "Pemberdayaan Guru Dalam Pembelajaran Matematika untuk Meningkatkan Kemampuan Berpikir Kreatif Siswa SD", Jurnal Ilmu Pendidikan . Jilid 18, Nomor 2, Desember 2012.

Yeni Rachmawati, Strategi Pengembangan Kreativitas pada Anak Usia TamanKanakkanak, Jakarta: Kencana, 2010. 